\title{
Chapter 10 \\ Inter-disciplinary Analysis of Climate Change and Society: A Network Approach
}

\author{
Jeffrey Broadbent and Philip Vaughter
}

\subsection{Introduction}

Networks matter. Whether a personal social network of contacts we use to navigate our daily lives, to globalized communication networks that connect governments, commerce, and social movements around the planet, networks are omnipresent. Social networking sites such as Facebook and Twitter have revolutionized how we network, as well as expanded the scale and sped up the time frame that we can now network on.

Social network analysis (SNA) examines the relationships among actors and ideas within social group. A relationship is any kind of transfer, from coercion and money to social approval and ideas, among people or groups of any size or level of organization. The vast and diverse network of transfers is central to reproduction of and change in social patterns and behavior, including how society relates to its ecological environment (Prell 2012). SNA is eminently applicable to studying the relations between society and the environment (Bodin and Prell 2011). SNA is interdisciplinary in the sense that it can be used to trace the flow of scientific and other ideas into the realm of discourse within society. From there, this flow of ideas can be followed to its impact upon political action and its outcomes. At the same time, it can be applied to different levels of society, from the micro inter-personal dynamics to the macro-global scale flow of new norms and alliances. SNA can also be used to isolate different dimensions of society, such as the composition of the discourse

\footnotetext{
J. Broadbent $(\bowtie)$

Department of Sociology, Institute for Global Studies, University of Minnesota, 909 Social Science Building, 267 19th Ave. S., Minneapolis, MN 55455, USA

e-mail: broad001@umn.edu

P. Vaughter

College of Education, University of Saskatchewan,

28 Campus Drive, Saskatoon, SK S7N 0X1, Canada
} 
field around a phenomenon, as well as the network of cooperation or information transfer among social actors. These flows and dimensions include the crucial feedback loops of grasping and framing a natural phenomenon wherein knowledge and belief, correct or not, are born and take life. Although providing the crucial substrate to social potential, molecular or genetic components cannot predict the formations and flow of society. SNA is inter-disciplinary, then, in the sense that it allows us to draw in the concepts and ideas about the natural and human worlds at all levels, and study how they work within the social and cultural arenas of collective human action.

Social scientists have taken note of the role that networks and networking play in social and political change, from improving safety conditions in nuclear power plants to negotiating new legislation on the supra-national level within the European Union. SNA has been used to analyze the discursive dimensions around political processes as well as coalition formation among organizations around environmental activism. The effectiveness of political or social movements is often determined by the nature of linkages between actors within a social network. Social network analysis can be used to examine political mobilization and the formation of advocacy coalitions as well as the spread of scientific knowledge and the dissemination of social or behavioral norms. By representing scientific knowledge as an information network along with other types of networks, a network approach can integrate the perspectives of different sciences (consilience) to study their conjoint and interactive effect upon the process of climate change production and solution.

And nowhere is the interaction between human society and the environment on a greater scale than in how our behaviors affect that greatest of global commons: the Earth's atmosphere. Increasing concentrations of greenhouse gases (GHGs) in the Earth's atmosphere from human industry have begun to change the planet's climate regime. And with the change in climate, have come changes to earth systems that humanity is dependent on. Sea levels are rising, threatening coastal communities; ice sheets have begun to melt, threatening fresh water supply; crops in some areas have begun to fail, threatening food supply. While human beings are adaptable, our capacity to do so will likely be overwhelmed as the scale of these impacts increase (IPCC 2007a). In order to reduce the emission of GHGs that spur climate change, norms of collective responsibility will need to be disseminated on a global scale (Broadbent 2010). But how will this happen? Indeed, can it happen?

When ozone depletion was operationalized as a problem within the 1980s, the driving force (production of chlorofluorocarbons or CFCs) was linked to a few specific activities (use of aerosol cans, use of specific refrigerants, use of certain packing materials) within a few economic sectors. The industries were able to substitute less harmful chemicals at low cost, and consumers did not have to radically change their behavior. Operationalizing climate change as a scientific certainty, let alone a problem, has been such a contentious debate because of the irreducible complexity of the issue. Greenhouse gases, which drive climate change, are not just produced by a few components of a few choice industries. Rather, they are omnipresent in virtually all economic activity and embedded within the production and maintenance of much of the globe's infrastructure. They are diverse in their 
source and type, creating debates over responsibility for their emission, as each greenhouse gas has its own global warming potential (GWP). Although carbon dioxide from industry and transport is the most abundantly produced anthropogenic greenhouse gas, methane emissions from agriculture cause more heat to be trapped within the atmosphere. To comprehensively tackle climate change as a problem, emissions from virtually every sector of the globalized economy must be addressed, not just a few choice "demon chemicals" from specialized sectors. Furthermore, because different societies around the globe have such varying sources of GHG emissions, national approaches to mitigation will have to be diverse rather than uniform. Mol (2001) has illustrated widespread norms and values in regards to the environment have diffused across the world, which seek to minimize the harm economic processes cause to the planet's ecosystems. However, this will take time to diffuse across different societies due to the scope and variety of climate change's drivers and impacts.

In the past, social scientists have studied how norms and values have been codified in international treaties on environmental issues (such as the Montreal Protocol) and how the design of these treaties have helped internalize environmental norms and values in societies around the globe (Schneider et al. 2002; Helm 2005; Speth and Haas 2006; Young 2002). However, constructs of environmental values or behavioral norms have been haphazard in regards to the threat of climate change, even with the drafting and implementation of the Kyoto Protocol. While some nations have made great progress in reducing their greenhouse gas emissions, others have not. Societies have varied greatly in their responses to climate change, and attention is now focused on what characteristics within societies are responsible for this variation. (Evans et al. 1993; Jacobson and Weiss 1998; Schreurs 2002, p. 261; Weidner and Janicke 2002, pp. 430-431) What factors have led to such varying norms and responses to climate change in societies around the world when global norms on policies around ozone depletion, ocean dumping, and pesticide use were embraced?

The authors of this chapter are part of a group of researchers, the Compon project, who propose that the next step in investigating these variables is to examine comparative policy networks in order to test hypotheses about social factors helping or hindering domestic responses to climate change. The project on Comparing Climate Change Policy Networks (Compon) project tests the effect of social organization, cultural meaning and political mobilization on a nation's response to climate change. The Compon project is a collaborative effort among teams of scholars using social network analysis to compare and contrast discourse and action around climate change and climate change policy within 19 societies around the globe. The societies currently within the study include Brazil, Canada, China, Germany, Greece, India, Indonesia, Ireland, Japan, Mexico, New Zealand, Portugal, South Korea, Sweden, Switzerland, Taiwan, the United Kingdom, Vietnam, and the United States. Using data collected by academic teams using the same instruments in these societies, social network analysis allows researchers to identify and compare patterns of belief, advocacy coalitions, mobilization and policy-formation as they shape the formation of mitigation policies and behaviors (Broadbent 2010; Broadbent 2013, \#3577). 


\subsection{Structure, Function and Power in Social Networks}

Network analysis concerns itself with the study of relationships among actors within a given network. New types of SNA approaches are incorporating not only actors, but also ideas or discourse, in the measured networks. One body of theory calls these ideas "actants," to distinguish them from willfully self-propelled "actors" (Latour 2005). The formal approach of Integrated Structurational Analysis (ISA) has been proposed to integrate the various dimensions in societal processes as network vectors among the units (actors and actants) (Broadbent 1998, 2003). The present section will discuss the approach and measures developed for social networks that can be applied to this kind of integrative synthesis and analysis. The essay will then distinguish social action and discourse networks and examine their interaction.

Depending on how the term 'actor' is operationalized, actors within social networks can be individuals (micro-level social networks), groups or organizations (meso-level social networks), or states in global relationships (macro-networks). To examine the networks that underlie and produce national-level policy formation, it is often appropriate to use organizations as the actor or social unit of analysis, as done here. The relationships between actors in a social network are described as ties, and represent a point of social contact between actors within the system. The social contact can consist of any type of interaction, be it the sharing of information or ideologies, the dissemination of a norm, or the exchange of support or resources. Much social scientific research, as is typical of survey research, has been conducted on samples of individualized actors. SNA differs because it also collects information on the relations or ties among the actors. If we want to study the ties as constituting a whole system, we have to study the group of actors that could potentially have direct ties among themselves. That rules out the random selection of actors from a large population (though one can study "ego-centric" networks that way). Rather, to study systems of relationships, we have to study the patterns of ties among a set of actors susceptible to relationships.

This kind of whole network study is applied to some kind of community, such as a classroom, a town, or in this case, a "policy domain." A policy domain refers to all the actors potentially influential upon a certain type of policy within a nation-state (or governmental area). The SNA approach takes into account both the qualities of the actors themselves, both their resources and their ideas, and the vital relationships that transfer those qualities as sanctions among the actors. The relational theory underlying the SNA approach argues that societal power is relational in that it involves the connection and mobilizations of numbers of actors and ideas. Hence, the relational ties are fundamental because they reveal the active flow of ideas and resources among actors that enable the power to affect policies and large scale societal changes.

One of the primary structural concerns within social network analysis (SNA) is identifying the "most important" or "most prominent" actors within a given social network (Wasserman and Faust 1997). The concept of actor importance is a measure 
of the property of actor location within a social network, with the most important actors being located in the most strategic locations within the network. Thus, an actor's role is characterized by its structural position within the network (Borgatti and Foster 2003). Actor centrality is the measure typically employed for quantifying an actor's role within a social network. A central actor is an actor with many ties to other actors within a network.

Bodin et al. (2006) note that a network actor with a high degree of centrality can effectively coordinate actors within the network during times of change. Burt (2003) characterizes these actors as "brokers" within social networks. In social networks the policy sphere, this means policies can be passed through a legislature more quickly, but Abrahamson and Rosenkopf (1997) contend this leads to centralized decision making within the network. Another implication is that actors within the network will have more limited access to other sources of information (Weimann 1982).

Another key structural feature of social networks is density within the network. Density within SNA is a quantifiable measure of connectivity between actors within the network and of the connectivity of the network as a whole. Density is not used as a measure of centrality per se; rather, it is a measure of the network's cohesion the number of links between actors within the whole network, not on an individual basis as with centrality (Wasserman and Faust 1997). Density of a network is calculated by dividing the number of links by the number of nodes within the network. One of the structural characteristics of dense social networks is a buffering capacity referred to as redundancy (Bodin et al. 2006). In dense networks, if an actor is removed from the network, because of the many links between other actors within the network, the loss does not have as profound an effect on the overall network structure. For advocacy coalitions, this means even if a central actors is removed from the coalition, other actors can step into the position and assume the functions of the central actor (Folke et al. 2005).

Social networks with greater connectivity of knowing each other exhibit higher levels of trust among actors within the network (Granovetter 1985). Pretty and Ward (2001) theorize that greater network density increases the possibility of social control of the actors within the network, which facilitates top-down regulation of the environment by the state. Oh et al. (2004) caution that dense networks can streamline policy processes, but may also promote homogenization of both experience and knowledge. Moreover, Frank and Yasumoto (1998) caution that too many links between actors within a social network can lock certain actors into inflexible positions, making political change difficult.

A concluding example of a structural feature of social networks is modularity or betweenness. Betweenness can be measured within a social network by quantifying the distance between nodes within a network. In any given social network, groups with high internal density may be loosely connected to other groups with high internal density. This phenomenon is termed modularity, and describes groupings of actors within a social network (Bodin et al. 2006). Within a civil society, this can be characterized by businesses having dense ties to one another, but weak or peripheral ties to government ministries or environmental NGOs. The betweenness of actors 
within a social network is a measurement of diameter - it is the number of steps needed to reach from one node to another within then network.

A high degree of betweenness in social networks allows different blocks of actors to interpret knowledge and develop policy responses distinct from one another. This is often the case in social networks around ecological governance, with different blocks developing different interpretations of data about the environment (Ghimire et al. 2004). The more modular a social network is, the less trust is demonstrated between different blocks within the network (Borgatti and Foster 2003). Likewise, it is more difficult to transfer tacit and/or complex knowledge ("externalize" scientific knowledge) within social networks with a high degree of betweenness (Reagans and McEvily 2003). In turn, advocacy coalitions characterized by high modularity within the network are prone to fragment, as the removal of a single actor can disengage a block of actors from the rest of the network (Borgatti and Foster 2003).

SNA sometimes assumes that higher centrality gives an actor more power over the other actors, and hence over the behavior of the whole network. However, this assumption is greatly in need of empirical testing in actual policy systems. The policy network approach taken by the Compon project includes measures of actor power in the formation of policy. One measure is created by survey respondents checking off those actors in the list they think to be very powerful within the policy domain (in this case, climate change). This is a reputational measure of power. Another measure involves the actor scoring their degree of satisfaction with the outcome of a policy debate in which they were involved. The higher the satisfaction, the measure assumes, the greater the effective behavioral power of the actor. These power measures can be used to trace the relative influence of different actors, their coalitions, and their ideas and ideologies - in this case about climate change. These measures were developed in earlier policy network studies (Knoke et al. 1996).

\subsection{Action Networks and Discourse Networks}

How different societies around the world respond to the call for mitigation of their emissions associated with climate change is a complex process involving a number of different interacting factors. The relevant factors can be broadly modeled as two different types of networks - discourse networks and action networks. Both types of networks have their own systemic dynamics and properties. Since both types of network are social phenomena, they are therefore more than the sum of the individual ideas and individual actions between actors in the field or domain. Social network analysis can be used to analyze the whole topography or morphology of these multi-actor, multi-idea fields.

The Compon project uses both types of networks to examine the social and political dynamics of mitigation policy formation and outcome in a number of societies. Use of the Discourse Network Analyzer (DNA) software enables the 
examination of the discourse around climate change issues and policies within a society's media and/or legislative records. Pioneered by Philip Leifeld, DNA applies the methods of SNA to study the actors quoted in newspapers and the policy positions they advocate. When analyzed by network analysis techniques, this data reveals the ideational cleavage lines between actors or groups of actors within a media discourse field particular to a given society (Leifeld and Haunss 2012). As such, this quantitative technique provides empirical data to the theoretical position stressing the importance of collective representations of (ideas describing) phenomena developed in Actor-Network Theory through qualitative research methods (Latour 2005). The discourse field includes the ideas from scientific research that claim to accurately describe and predict natural phenomena as well as ideas welling up from less disciplined human processes that cloak such scientific claims in popular preferences and prejudices. This type of interaction has been deeply investigated in research on science and society (Jasanoff 2005). DNA allows the more precise identification of different types of discourse and their degree of support by political actors.

The other type of SNA, termed the policy network method, is used to investigate the relationships between actors active in the climate change policy sphere. The policy network method grew out of the quantitative network analysis developed in the 1960s and first applied to small groups or communities. The policy network analysis (PNA) approach turned that technique to study the policy formation process as influenced by organizations, including agencies within the state and associations with society as an interactive polity. Researchers first used PNA to examine American and German political processes during the 1970s (Laumann and Pappi 1976). They subsequently expanded the approach to compare Germany, the US and Japan (Knoke et al. 1996). As distinct from the newspaper discourse analyzed by DNA, the policy network survey gets responses about their ideas, resources and networks directly from representatives of the groups and organizations involved in the policyinfluence process. The survey data therefore allows for a precise examination of the discourse (policy stances, beliefs, ideologies) held by organizations as well as their coalition formation, political pursuits and degrees of influence. The use of a standardized basic network survey in multiple cases (nation-states or areas) allows for rigorous cross-case comparison and the search for common causal factors leading to emissions trajectories (from 1990 to present, in sum increasing, reducing, or level) (Broadbent 2010).

\subsubsection{Culture as Context in Social Network Analysis}

When using SNA for comparative approaches (for instance in comparing different nations' carbon policy outcomes), it is important to remember that social networks around discourse and action emerge from and operate within a context. That is to say, neither actors, ideas or relationships are autonomous units. They differ in each situation, in this case in each nation-state policy network. In philosophical terms, 


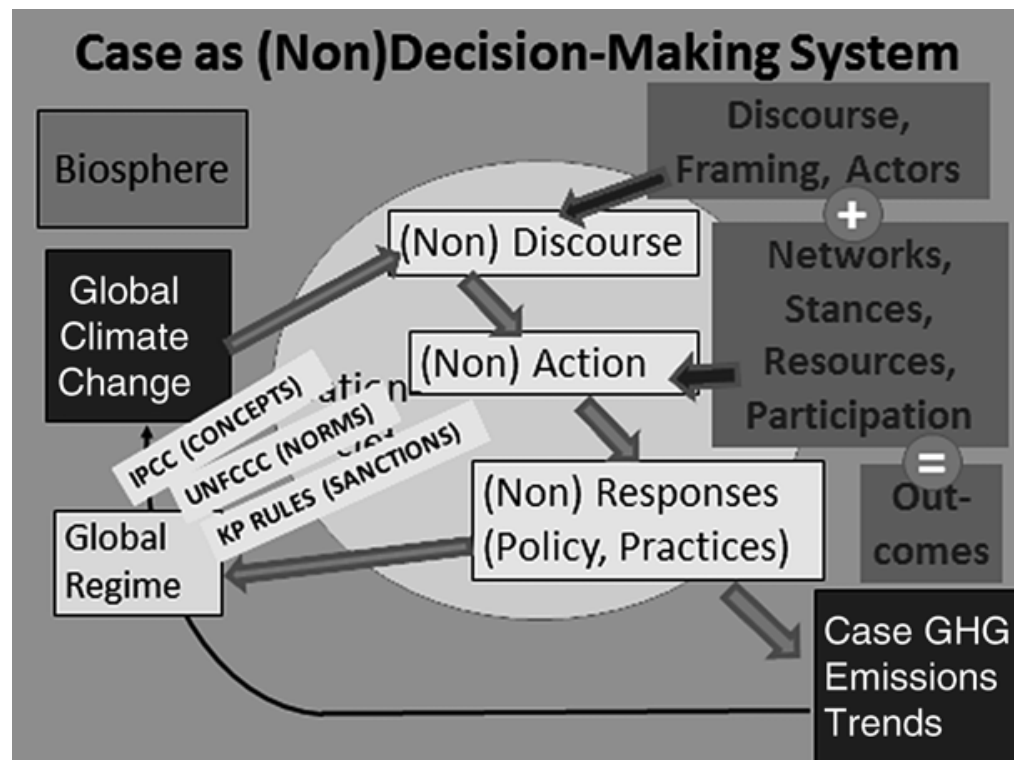

Fig. 10.1 Model of social response to climate change

those "units" take shape within and help constitute unique social/cultural ontologies (ways of being). The components are formed and operate under basic social conditions (variously referred by different schools of social science as institutions, structures or systems) that constrain, facilitate and channel the possibilities of both discourse and action within a given society. This can be more broadly defined as a nation's cultural framework. Existing cultural and social conditions constrain the emergence of new discourses and the possibilities of their application to create change. Depending on the nation in question, contextual factors can make the dynamics of either field more or less solid and enduring or fluid and volatile. The more fluid the system, the more that actions interact with discourses to produce new forms of power and in the current concern, change societal practices and political policies affecting climate change mitigation.

Figure 10.1 presents a hypothetical model of that process within the national arena and between national and international levels (Broadbent 2010). Climate change as a geophysical process driven by human-caused carbon emissions enters the society as conceptual information. These concepts are processed through societal discourse and action and eventually "constructed" or rejected as usable knowledge by different advocacy groups. This "construction" process is profoundly influenced by local factors of the society itself, such as culture, institutions, level of economic development and others. The mixed effect eventuates in decisions or non-decisions with effects upon the carbon emissions trajectories of the society. These emissions in turn feed back into the global geophysical situation and its propensity to produce climate change and disastrous effects on societies. As societies 
repeat these processes, they also build up through global negotiations a global climate regime - a set of ideas, norms and rules that may exert increasing influence upon the decision-making processes of member societies.

Many studies have tried to attribute attitudes on the environment and on the science that explains the state of it to different demographic characteristics of populations. Research has shown that public perceptions of risk are widely divergent within different national populations (Siegrist et al. 2005). Different social groups in different nations have different issues of contention around different scientific claims (Walls et al. 2004). Thus, demographic characteristics such as age, race, or sex may be poor predictors of attitudes towards science, risk, or environmental values within cross-cultural comparison for an issue such as climate change. Rather, a person's cultural framework serves as a better explanatory framework for how or why scientific knowledge (such as climate science) is valued or accepted (Jaeger et al. 1993). How successfully concepts of risk are understood (Slovic 1986) or scientific claims are communicated is largely a function of how science itself is framed within a given political and/or cultural environment (Jasanoff 1998). In cultures that employ a 'science-centered' paradigm, it is the duty of scientists to inform the ignorant state and to educate the irrational public as to what "real" risks are, and to provide advice on how to handle them (Tversky and Kahneman 1974). The robust environmental policies created around the globe between the 1960s and 1980s were facilitated by cultures that embraced this 'science-centered' paradigm; in these democracies the public considered science as both credible and relevant (Gustafsson and Lidskog 2012). In a political culture that values public opinion, but where the 'science-paradigm' is not accepted, environmental concern - and therefore the science that underpins it - may be marginalized by a public whose primary concern is the economy. In this 'economy-paradigm,' perceptions of risk to the economy may outweigh the perception of risks of damage to the environment.

Brown Weiss and Jacobson (1998) observe that environmental concerns tend to be brushed aside if they pose a risk to the economy within societies that value participatory democracy and employ the 'economy-paradigm.' Indeed, it has been argued that democracies are ill-equipped to deal with ecological concerns, as the public tends to vote in their short-term self-interest (Giddens 2009). Shearman and Wayne Smith (2007) speculate that cultures that value both democracy and economic growth will continue to ignore the implications of climate science, even if actors within democracies accept that science as valid, because transient issues will outweigh such a permanent and entrenched issue within the electorate. This tendency to ignore, if not all out reject, scientific information that is deemed inconvenient for a society is termed 'the triumph of short-termism' (Clayton et al. 2006). Giddens (2009) characterizes this tendency as 'loss aversion,' with the voting public more concerned about perceived losses than with future gains.

Cultures that tend to legitimize governance through majority rule, even when the majority may not be informed about an issue they are voting on, may have trouble cobbling together enough actors to form effective communication networks around climate change discourse or advocacy coalitions around climate change policy. This has opened up a transnational debate as to whether environmental regulation 
should be based on the advice of experts or whether regulation should be legitimized through democratic consensus (Collins and Evans 2007; Renn 2008). By the time climate change became a prominent environmental issue during the 1990s, a coalition of actors had arisen within the United States that was both critical and hostile towards scientific reports on climate change (Hamilton 2007). Among the criticisms launched at the climate science community were that the models of climate change should aspire to scientific certainty for the prediction of hazards (Baker 2007), that scientists were attempting to usurp the role of the state's authority (Jasanoff 1998), and scientific uncertainty around climate change had to be reduced before the climate science community could make policy recommendations (Brown 1992). All of these criticisms were criticisms that previous environmental issues had not had to contend with, or at least, not contend with to such an extreme. But because regulation based on science began to be framed as only legitimate through democratic consensus within American culture, a culture where scientific evidence could be contested because of democratic values became normative within the United States.

The issue of uncertainty has since emerged from American culture to become a rallying call to question all discourse around climate change and delay any mandatory regulation of greenhouse gas emissions within the United States (IPCC 2007b). The same tactics to create a culture of doubt around climate science have spread across the Pacific to democratic societies such as Australia and New Zealand (Hamilton 2007). The scientific community in many different democratic societies have been divided over how to respond to increased public scrutiny, with calls to reestablish a culture of communication between scientists and the public as authoritative rather than debatable (Collins and Evans 2007; Renn 2008), as well as a push to dialogue with the public over scientific knowledge (Jasanoff 2005; Lidskog 2008).

Thus, even if science is accepted within democracies, it may not be effective in setting policy objectives if the citizenry does not agree with the implications of science on regulation. This is not to suggest that cultures that value authoritative governance are uniquely equipped to deal with climate change; far from it. Indeed, authoritarian cultures have their own unique problems in addressing environmental concerns, including a lack of willingness to engage stakeholders and problems with adaptive management. Instead, the preceding examples are meant to illustrate to the reader the importance of context (both political and cultural) when examining both the discourse and action networks around climate change within a given society.

\subsubsection{Discourse Networks Around Climate Change}

The field of discourse represents the distribution of concepts (perceptions, beliefs, knowledge) and their meanings (interpretations, evaluations, frames, emotions) about prevalent in a society (Broadbent 2010). While resources and support are often traded between actors in a social network, so too are concepts and meanings, including an understanding of scientific principles. Engagement with science and an 
understanding of scientific inquiry have become embedded as norms within a number of societies around the globe (Beck 2002; Höijer et al. 2006). Individuals engage in discourse over science not only through formal education, but also increasingly though informal means, such as the news media and interpersonal communication (Van Dijk 2011). Organizations too must engage discourse over science, though the manner in which scientific knowledge and methods of scientific inquiry are institutionalized and normalized within organizations is not well understood. Watson (2002) contends that organizational learning is poorly conceptualized, meaning a systematic investigation of how organizations process and gain knowledge has been difficult to implement. Compounding this deficit in knowledge is the fact that the research that has begun to investigate how organizations learn has focused on the transmission of cultural, financial, or legal knowledge rather than beliefs institutionalized through gained scientific knowledge.

Communication networks are described by Hajer and Versteeg (2005) as discourse spaces where actors explain themselves in order to exert influence over other actors. Structural characteristics of discourse networks are important for understanding how effectively scientific knowledge is communicated between actors within a communication network. The density of a social network is the most widely used measure of group cohesion, with denser networks having more ties between actors (Blau 1977). Essentially, density quantifies network "knittedness" within SNA (Bott 1957). Dense networks facilitate the dissemination of scientific information in a communication network by increasing the accessibility of information in the network (Abrahamson and Rosenkopf 1997). In addition, networks with high density promote the development of universal norms in regards to natural resource management and environmental policy; they also promote compliance with these norms (Coleman 1990).

Because the geophysical and climatological processes involved in climate change are complex and require a specialized scientific background to understand them, non-specialists must rely heavily on scientists to frame and explain the problem. Scientists were relied upon to communicate risks on a number of environmental issues to a diverse network of actors during the latter half of the twentieth century. These issues included pesticide use, damage to the ozone layer and the impacts of radiation from nuclear weapons . However, faith in the scientific community has been heavily contested in regards to climate change. The framing of climate science as contentious rather than authoritative was facilitated by regulatory failures (Power 2007), an increasingly scientifically literate citizenry capable of questioning scientists (Nowotny et al. 2001), and a greater emphasis on individualization in a number of societies across the globe (Beck 1992). Scientific claims were no longer viewed as objective and scientists themselves were beginning to be viewed as untrustworthy. Climate scientists in particular began to be viewed as actors whose interests were in conflict with the interests of the public, the business community, and the state (Gouldson et al. 2007).

When information about climate change moves through the discourse field (contested or otherwise), evaluative norms come into play. Evaluative norms spread through discussion networks among organizations and individuals, as well as 


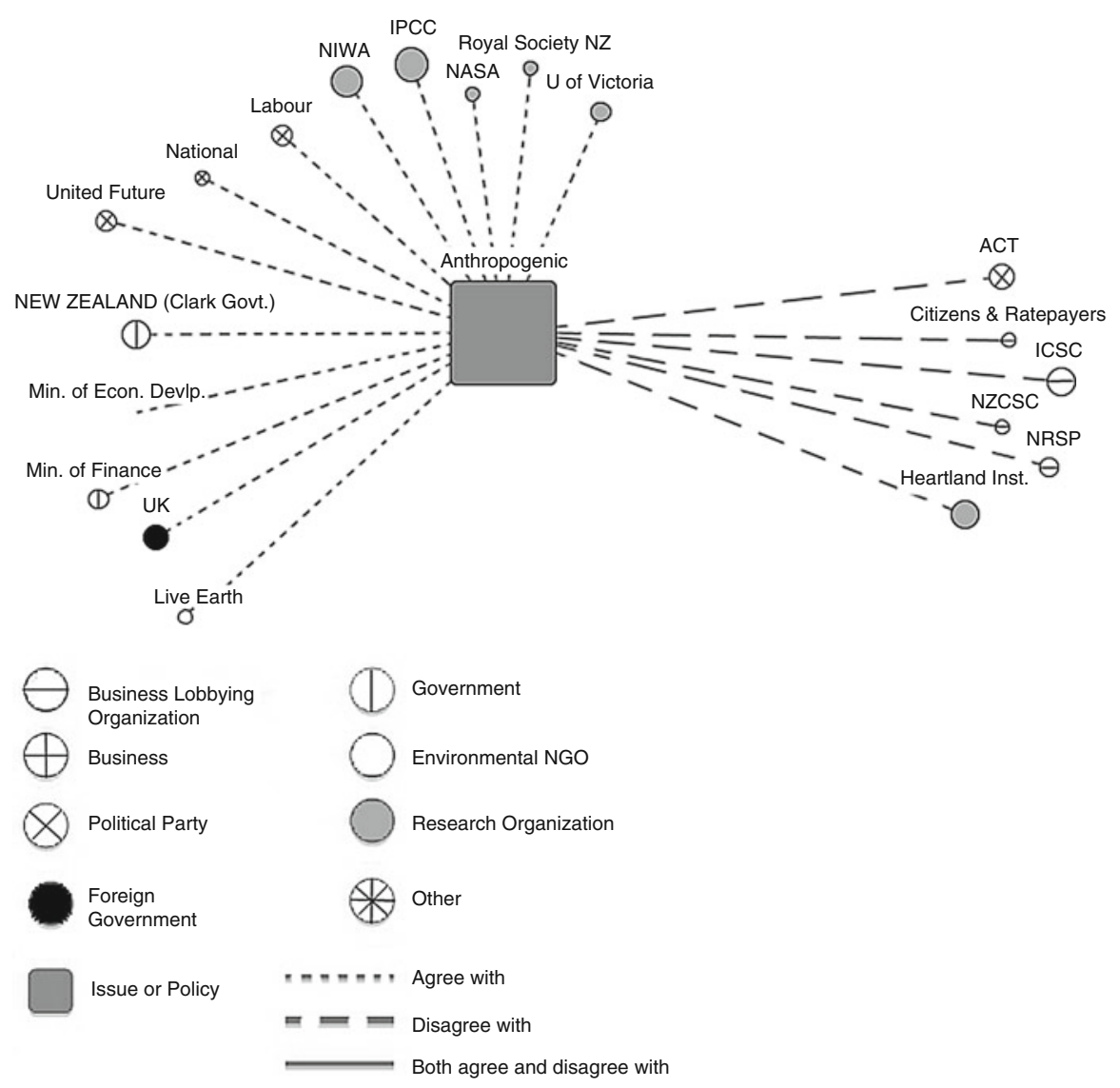

Fig. 10.2 Discourse network on legitimacy of climate science within New Zealand press, 2007-2008

through mass and specialized media (Broadbent 2010). The discourse network diagrams pictured below (Figs. 10.2 and 10.3) show the positions of organizations within New Zealand and the United States respectively on this issue (square) of climate science between 2007-2008. These diagrams were created using the software tool Discourse Network Analyzer (DNA) (Leifeld 2011) where the size of each actor node (circles) represents the number of statements made about the issue within a sample of the nation's news media.

Within the New Zealand discourse network (Fig. 10.2) around the validity of climate science, the media portrayed a wide consensus on the domestic stage around the validity of climate change science. Organizational actors who accepted the evaluative norm that climate change was real and anthropogenic include Clark's government ministries, most political parties (Labour, National, and United Future through statements to the press, Green, Māori, and New Zealand First through statements on television), as well as most research organizations (domestic and foreign) 


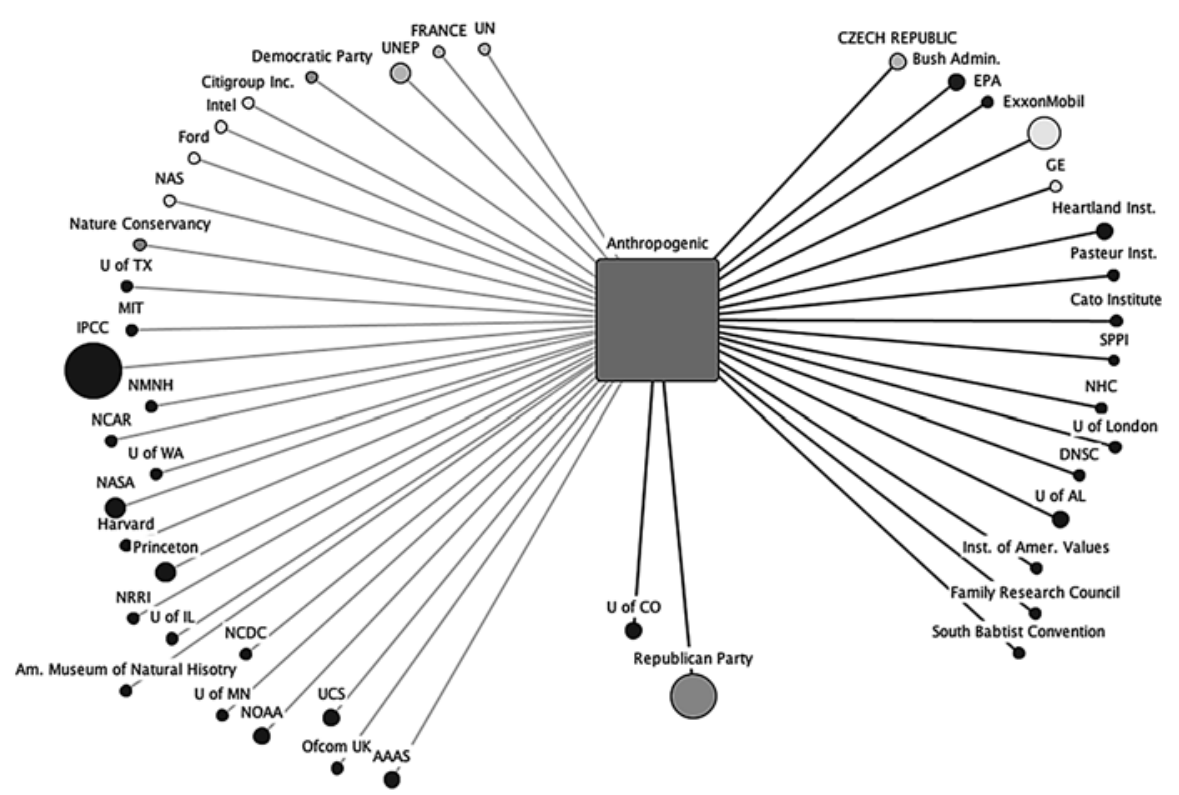

Fig. 10.3 Discourse network on legitimacy of climate science within United States Prestige Press, 2007-2008

quoted by the press (Vaughter 2013). Organizational actors who rejected or questioned the evaluative norm that climate change was real included a variety of business lobbying groups, though no businesses themselves. The ACT Party is the only political party that refuted the validity of climate science, and the only research institute (the Heartland Institute) to refute it within the New Zealand press was from the United States. Within the New Zealand press, the discourse over the legitimacy of climate science is unquestioned by the government, and the majority of all research organizations and political parties.

Because the science supporting climate change appears well accepted by both the scientific community and political actors within the New Zealand press, the majority of debate about climate change covered by the press is not about operationalizing climate change as a problem, but rather on how to implement a solution. Clark's Labour government and its constituent ministries, in coalition with the Green and New Zealand First Parties, comprise the majority of actors cited as pushing for a series of legislative solutions. This coalition of actors often stressed the 'science-paradigm' for legitimizing their proposed actions through citing both the IPCC and NIWA data in setting the time frame for implementing these policies. The opposition National Party in coalition with the Māori Party, accepted the scientific findings of the IPCC and NIWA as well and agreed climate change was an issue New Zealand needed to address. However, both parties viewed the Labour coalition's time frame for implementing an economy-wide ETS as reactionary, 
with negative repercussions for New Zealand's economy and the autonomy of indigenous groups. These actors often employed the 'economy-paradigm' by citing economic data from the New Zealand Institute to illustrate the costs of implementing an economy wide ETS as quickly as the Labour coalition wanted. Within this group of actors, the 'science-paradigm' was accepted but discounted in favor of the 'economy-paradigm.' Businesses and environmental NGOs stayed out any discussion of climate science, and instead advocated for or against specific pieces of climate legislation.

The discourse networks about anthropogenic climate change in the US (Fig. 10.3) contrast distinctly with those of New Zealand. In this discourse network the legitimacy of climate science is contested rather than accepted by government actors such as the Bush Administration. In addition, while the majority of research organizations within the New Zealand discourse network are quoted as supporting the legitimacy of climate science, there is a more even split between positions within the research organizations cited in the American discourse network. This spit frames climate science as more controversial, with reporting on both perspectives being more "balanced," despite little controversy within the climate science community itself (Boykoff and Boykoff 2004).

Actors within the American discourse network around climate change science appear much more divided in whether they accept or reject the 'science-paradigm' The cultural backdrop of the United States can also be glimpsed within this discourse network, with three fundamentalist religious groups weighing in on the issue, while religious groups are absent within the more secular New Zealand discourse network.

By portraying the climate debate as unsettled, the U.S. discourse network around climate change presents an inherent contradiction in its coverage of the issue. The debate over climate science occurs alongside discussions regarding the best ways to mitigate climate change. These two debates challenge each other's legitimacy, the former implying that the latter is premature, and the latter assuming that the former has already been settled (Burridge et al. 2013). The further disagreement and contradiction between cited research organizations over climate change further fuels this fire by failing to present a unified or even majority viewpoint on the issue. As Boykoff and Boykoff (2004) note, this tendency for the media to represent support for and skepticism of climate science in roughly equal proportions is not representative of the positions held by the science community, which overwhelmingly accepts the science behind climate change. The overall effect of this contradiction in media coverage produces a diffuse and convoluted definition of the issue that fails to identify what element or elements of the problem are actually in question. And without a clear definition of the problem, neither the public nor their elected officials will be able to begin operationalizing solutions with any success.

While discourse around climate change within the US is prominent and contains a number of diverse organizational actors, the stances of the predominant actors in the debate are inconsistent in regards to discourse around climate change policy (Fig. 10.4). Decision makers appear to bend to whichever way their constituency blows, with little agreement within political parties as to how climate change should 


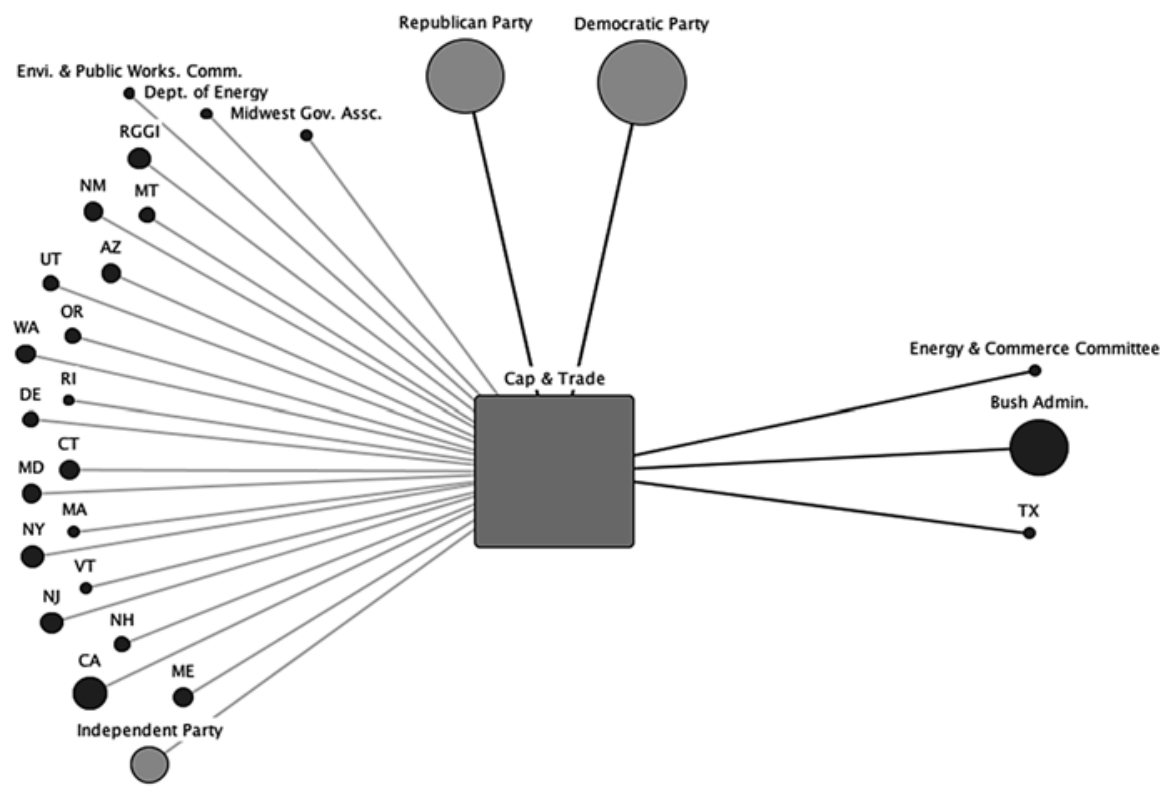

Fig. 10.4 Discourse network on federal cap and trade legislation in United States Prestige Press, 2007-2008

be conceptualized, let alone handled. The reluctance of either political party to operationalize solutions to the problems presented by climate change is unsurprising, given the lack of agreement among decision makers as to what the problem is. The Democratic and Republican parties both agree and disagree with a federal cap and trade mandate, at the same time the Republican Party is portrayed as both agreeing and disagreeing that climate change is a problem.

Discourse networks can be used not only to probe actors' normative stances, but can be employed to examine how information is disseminated within a society. Organizational actors learn through their networks as well as peer pressure about what evaluations (frames) to adopting regards to climate change. The dissemination of science, especially climate science, is never an easy task, because science itself is an iterative process, with an understanding of what is 'objective reality' changing and evolving over time. Some organizations can influence the flow of information to actors in a network, imposing frames of understanding upon them, or the diffusion can be interactive, through rational discussion among peers. In other instances, diffusion of knowledge may be blocked by certain actors within a network, or the implications of this knowledge may be discounted if they run counter to other concerns a given organization is facing. Actors using different normative standards will necessarily disagree about what to do. Only some actors will accept sufficient responsibility to seriously think about, evaluate and act upon the issue (Broadbent 2010). 


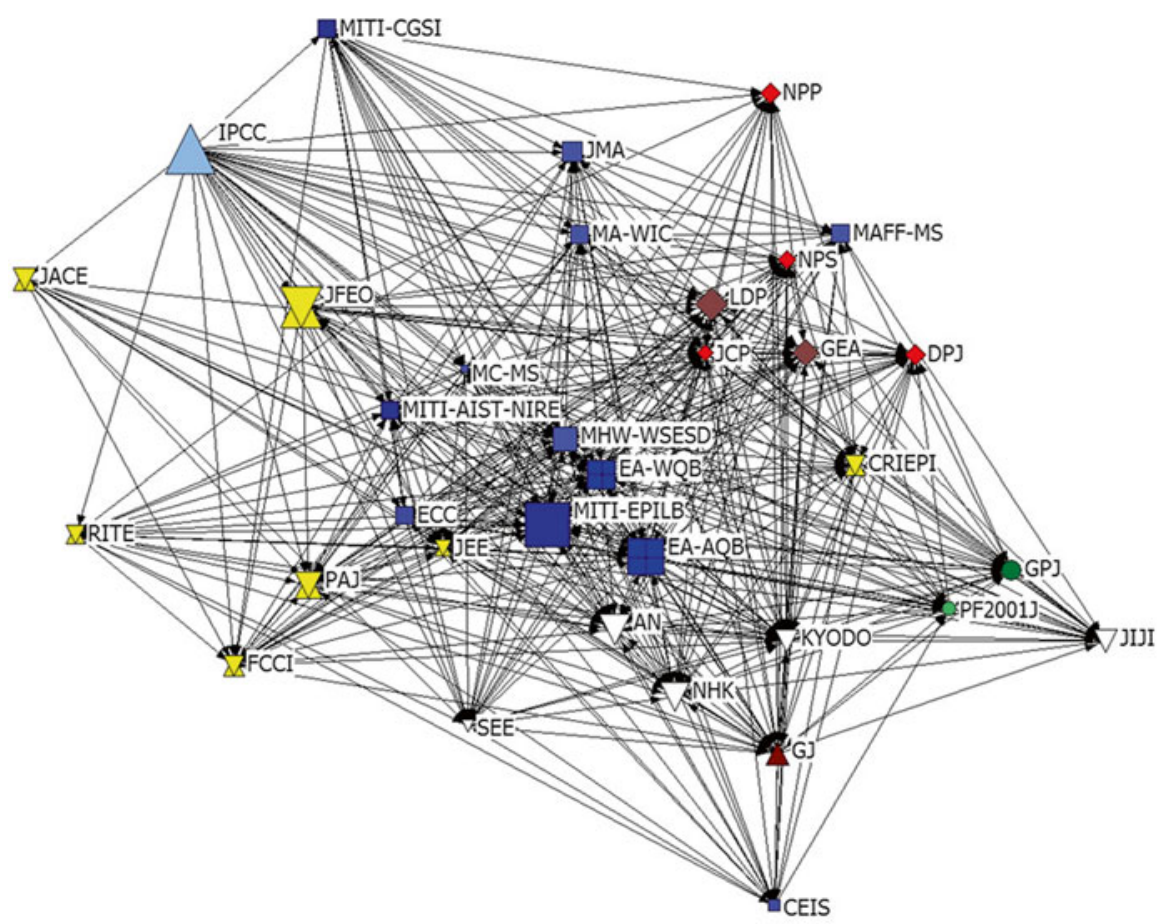

Fig. 10.5 Japanese organizational actors receiving information directly from the IPCC.

Tracing the flow of information and norms through networks will help indicate the function of organizations in a network. With optimal function, such forums may help the diffusion of scientific evidence and risk evaluation. For climate change, the Intergovernmental Panel on Climate Change (IPCC) has emerged as the predominant organization producing scientific information in relation to the topic. Thus, an examination of how information from the IPCC is disseminated from the organization into the civil society of a given nation can help inform how the IPCC functions as an actor within that nation's network of political actors. This in turn can illuminate how knowledge about climate change is conveyed within a society, and how actors evaluate the risks associated with climate change and construct responses to these risks. In the network data analysis, if a diversity of organizations have information networks to such a forum, and also hold scientific and action-oriented norms, it will indicate that the forums do indeed have the predicted function.

The network image in Fig. 10.5 shows how information about climate change was disseminated to a large and diverse set of organizations in Japan during 1997. The organizations include a large number of government agencies (blue squares), and large number of business organizations (yellow double triangles), some political parties (the brown and red diamonds), two environmental NGOs (green circles) and 
many media companies (white triangles). ${ }^{1}$ The remaining brown triangle is Globe Japan, an international association of national politicians concerned about global environmental issues. The size of the icons reflects their perceived level of influence in Japan's domestic politics of global environmental issues (as determined by the number of respondents checking that organization as being "especially influential"). The communication network indicates that in the 1997 Japanese global environmental policy domain, the IPCC was among the big three influential organizations. Among the government ministries and agencies, the Air Quality Bureau of the Environmental Agency (AQ-EA) is second only to the Ministry of International Trade and Industry (MITI). The network image also reveals strong levels of perceived influence for the three news media clustered close to the government agencies. The Liberal Democratic Party is also assessed as highly influential, while the Japan Communist Party is diminutive. Business associations do not receive climate change information directly from the IPCC. Rather, businesses hand over this information-gathering task to a specialized business research institute, the Research Institute of the Electric Power Industry (CRIEPI), from which they probably get most of their information. Almost all of the domestic environmental NGOs do not receive information directly from the IPCC. Instead, the Japan branch of Greenpeace International serves as the primary information bridge-keeper to the domestic NGO community. This network figure indicates that in Japanese society the information bridge-keepers between outside and inside are relatively few, and those that perform this role have relatively high levels of political influence. This finding is in line with the network theory that being a bridge-keeper over a structural hole (a gap between clusters of organizations) gives power to the bridging actor (Burt 1992; Broadbent 2010).

Upon examination of the Japanese communication network about climate science, Japanese society appears receptive to the logic of scientific evidence - indeed the culture is enamored of technology and very successful in its innovation - and relatively free of powerful belief systems that would militate against accepting such logic. Compared to US media, Japanese news media are closely dependent upon government ministries for information and have rarely presented views questioning the validity of the IPCC findings and assertions. Japan's climate change science establishment is closely tied to and funded by the government. It seems that Japanese climate scientists rarely act as autonomous knowledge brokers among different sectors or in the policy making process, nor do they directly address the public contrary to current government policy (unlike, for instance, top climate scientist James Hansen in the US) (Broadbent 2010).

As an extension of this research to the global level, a publication based on the Compon media content analysis analyzed the comparative response to the 2001 and 2007 reports by the IPCC among five Asian societies (Broadbent et al. 2013). This study found different intensity of coverage in China, India, Japan, South Korea and Taiwan. However, the fact that Taiwan, not a UN member, always had the

\footnotetext{
${ }^{1}$ Note: the color version of this figure is available online in the Open Access version of this book, the print version includes grey scale images.
} 


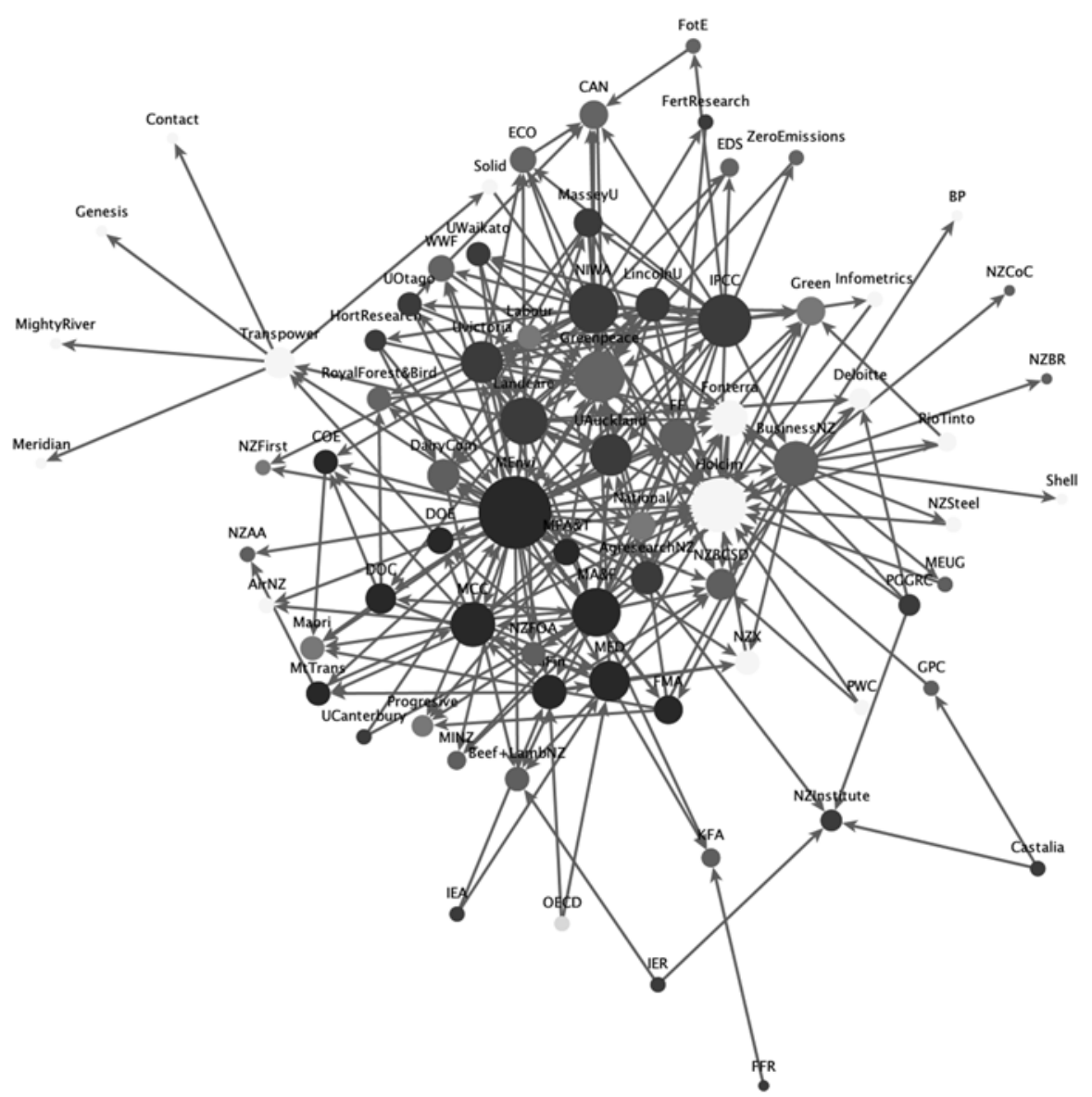

Fig. 10.6 New Zealand organizational actors receiving scientific information about climate change.

lowest coverage indicated the importance of belonging to the UN system for receptivity to UN-based ideas.

Figure 10.6 shows how information about climate change was disseminated within New Zealand in 2008, in the lead up to the implementation of its economywide emission trading scheme. Organizations featured in this network include government ministries (blue circles), business organizations (red circles), political parties (orange circles), environmental NGOs (green circles), and research organizations (purple circles). ${ }^{2}$

As with the Japanese network in Fig. 10.4, the size of the icon represents the level of perceived influence of the actor in disseminating knowledge about climate change.

\footnotetext{
${ }^{2}$ Note: the color version of this figure is available online in the Open Access version of this book, the print version includes grey scale images.
} 
As within Japan, the IPCC is one of the three most central actors within the network. Another highly centralized actor within the network is the National Institute of Weather and Atmosphere (NIWA) a state owned and operated Crown Research Institute responsible for much of the climatological data submitted by New Zealand to the IPCC. The Ministry for the Environment (MEnvi) is the actor responsible for the majority of dissemination of scientific information on climate change to other actors, having the greatest centrality score of any of the actors within the network. The Ministry of Economic Development (MED) and the Ministry for Foreign Affairs and Trade (MFA\&T) also figure prominently in the communication network, as well as several other Crown Research Institutes and domestic research universities. None of the political parties are presented as especially critical to information transfer, though the majority of political parties do appear within the network. Like in the Japanese case, businesses (yellow circles) tend to receive most of their information from business lobbying groups (red circles). While most of the domestic environmental NGOs do receive information from both the IPCC and NIWA, they do not in turn seem to give information about climate change to many actors within the network. This network figure indicates that within New Zealand the organizations conducting research on climate change themselves as well as the Ministry of the Environment act as bridge-keepers between actors within society, suggesting a high level of political influence.

In examining the New Zealand communication network around climate science, New Zealand also appears receptive to scientific evidence produced by the IPCC and its constituent organizations, many of which appear as Crown Research Institutes within this network. While the New Zealand media does present views questioning the validity of the IPCC's findings and assertions, the actors cited as doing so are not often research organizations as in the American media. While New Zealand climate change science organizations do not act exclusively as knowledge brokers among diverse clusters of actors, the do play an important role of being the sources of scientific information for those actors that do act as knowledge brokers.

\subsubsection{Policy Networks Around Climate Change}

The field of action represents the behavior of actors - individuals, organizations, states - as they interact to promote or oppose change, often though policy. National policies interact with and help or hinder the formation of global regimes (Broadbent 2010). Sabatier and Jenkins-Smith's (1993) concept of the Advocacy Coalition Framework (ACF) uses network structures in order to investigate action through policy processes. One of the original goals of the ACF was to investigate how actors mobilized within advocacy coalitions around scientific information to inform environmental policy (Weible et al. 2011). In order to do this, actors must identify allies with common objectives they are willing and able to enter into coalition with 
(Weible and Sabatier 2005). The prevailing evidence indicates that actors with similar beliefs about the implications of scientific knowledge tend to coordinate with each other on actions (Zafonte and Sabatier 1998). However, recent research by Baldassarri and Diani (2007) has shown that support networks connect diverse clusters of organizations with common general beliefs but distinct organizational identities and priorities. Di Gregorio (2012) terms this process 'macro-integration' - where robust support networks are formed by organizations which do not necessarily have collective identity or set of values but their distinct identities and value sets are compatible enough to form a coalition. In this instance, action is most effective when actors with a common purpose but diverse identities network.

The study of advocacy coalitions has traditionally framed coalition building and function within the context of political contention. In this case, advocacy coalitions fit within the field of action. The theory of the Treadmill of Production (Schnaiberg et al. 2003) contends that measures to protect the environment will be met with severe opposition from industrial and exploitative actors within society. In this scheme, the only way to bring about change to the environmentally destructive status quo is through massive social mobilization. This social mobilization can manifest itself through demonstrations, boycotts, electoral victories, the passing of regulatory legislation, or some combination of all of the above. However, advocacy coalitions can also be framed as instruments of influence and instruction. In this case, advocacy coalitions fit within the field of discourse. The theory of Ecological Modernization (Janicke 2002; Mol and Sonnenfeld 2000) maintains that protections to the environment can be brought about through more passive means. In this instance, behaviors that protect ecosystems are brought about through the dissemination of norms, the diffusion of new ideas, and a non-politicized learning process (Broadbent 2010). Here, advocacy coalitions bring about change through consensus rather than through contention. In the following sections, we will be examining advocacy coalitions within the framework of the action field.

The implication of social network analysis (SNA) around environmental advocacy coalitions is an increased understanding of what features of social networks are necessary precursors for successful advocacy around environmental policy in general, and climate change policy in particular (Bodin et al. 2006; Crona and Bodin 2006). Tompkins and Adger (2004) put forward that social networks with more ties between stakeholders and regulatory actors builds resilience and adaptive capacity to environmental change in societies. However, there has been little research into the relation between network structure and specific policy outcomes. Additionally, while social movements are well studied within the social sciences, advocacy coalitions are less so. It can be difficult to tease apart the differences between an advocacy coalition and a social movement, but there is a growing need to within the literature, as advocacy coalitions continue to engage an increasingly diverse set of stakeholders around issues as complex as climate change.

In order to change behavior at a social level, the initial bearers of claims and norms must expand networks: persuade an increasing circle of adherents until their number and activity reaches a critical mass (Broadbent 2010). In this process, 
knowledge must be operationalized and social learning must turn into social mobilization. In order to effect change in response to the knowledge they are claiming as legitimate, advocacy coalitions need to garner enough political support to enable them to pass and enforce regulations and laws that demand and enforce certain environmental standards. These policies can become manifest through legislation such as an emissions trading scheme (cap and trade law) or some other form of emissions regulation (i.e., a carbon tax). In order to do this, advocacy coalitions must form connections with a larger and more diverse set of actors within a society to achieve this critical mass. When a mobilized advocacy coalition garners enough support to form a majority government, or gains enough support to push a government on a particular piece of policy, it begins to exert power within the state, through the legislative and policy-making process. From that vantage point, the new regime can establish the legal and policy conditions to bring about society-wide change in behavioral norms (by education, persuasion, inducement, regulation, new institutions and other means) (Broadbent 2010).

The political strength of advocacy coalitions in taking action to push for climate change legislation appears to vary depending on the cultural milieu of the society in question. In Sweden, where social corporatism is the norm within the political culture, there is a diverse representation of actors within the advocacy coalitions centered around climate change legislation. This included incorporation of a large number of environmental NGOs within the Swedish policy sphere. Within the US, the political culture is one of pluralism. Ironically, this leads actors to compete with one another for dominance within the policy sphere, with the wealthier business entities (often opposed to climate change legislation) exerting more influence. This can lead to more environmental NGOs being left outside the political process.

Organizational actors who work in tandem within an advocacy coalition on the political stage are central players within the study of social networks. Such networks often build upon longer existing relationships, such as the long-term exchange of mutual aid (reciprocity). These networks suffuse societies in different densities and patterns, helping give rise to different policy making processes. For instance, the reciprocity network penetrates the full Japanese field of labor politics very thoroughly, but in the US is only present among labor unions (Broadbent 2001, 2008). In the Japanese case, the presence of reciprocity networks increased the likelihood that the so-connected actors would transfer political support.

Broadbent (2005) notes that in Japan's action phase, advocacy coalitions have played a weak role in influencing national climate change policy. Frames concerning national prosperity and energy sufficiency formulated by the Ministry of Economy, Trade and Industry have dominated debates about climate change, rather than fears about the future disasters that climate change will bring such as presented by the Environment Ministry. The close alliance between the ruling Liberal Democratic Party and the corporatistic business sector led by the JFEO (Japan Federation of Economic Organizations or Keidanren) have further buttressed a weak political posture toward climate change insisting on voluntary action by business and no carbon tax on consumption rather than the imposition of regulations by government. 
On the other hand, in New Zealand advocacy coalitions have played a vital role in passing domestic climate change legislation. In terms of scope, coverage, and speed of implementation, New Zealand's national emissions trading scheme (ETS) is arguably one of the world's most ambitious climate policies. Passed by the outgoing Labour government in late 2008, the ETS covers all six greenhouse gases (GHGs) listed within the Kyoto Protocol. The current incarnations of the European Union's ETS, as well as the Swiss and Norwegian ETS, cover only the emissions of carbon dioxide $\left(\mathrm{CO}_{2}\right)$. By regulating methane $\left(\mathrm{CH}_{4}\right)$ and nitrous oxide $\left(\mathrm{N}_{2} \mathrm{O}\right)$ under the scheme, New Zealand opened up sectors of economic activity to emissions regulation, such as agriculture, forestry, and land use change, which had typically been ignored in Europe (Moyes 2008). What is remarkable about this is that New Zealand is by and large an agricultural export economy, unique within Annex I nations, with a large share of its greenhouse gas emissions coming from agriculture and forestry. The average proportion of GHG emissions from post-industrial nations are $83.2 \%$ $\mathrm{CO}_{2}, 9.5 \% \mathrm{CH}_{4}$, and $5.9 \% \mathrm{~N}_{2} \mathrm{O}$ (UNFCCC 2007). At the time the ETS was drafted, New Zealand's GHG emissions were $46.5 \% \mathrm{CO}_{2}, 35.2 \% \mathrm{CH}_{4}$, and $17.2 \% \mathrm{~N}_{2} \mathrm{O}$, with HFCs, PFCs, and $\mathrm{SF}_{6}$ together accounting for the remaining $1.1 \%$ of total GHG emissions (Ministry for the Environment 2007).

While New Zealand's policy instrument of choice for dealing with climate change generated substantial debate within both parliament and the press, a large proportion of organizational actors within New Zealand society accepted the frame that climate change was a long-term threat to the nation and that a policy approach was an appropriate response. A number of the ministries within the Labour government, three of the nation's major political parties, that nation's alternative energy companies, the airline industry, and a slew of businesses and environmental NGOs supported the creation of a comprehensive ETS. A coalition of agricultural and industrial business lobbying groups, and two of the nation's smaller political parties opposed the passage of the ETS. The opposition National Party conditionally supported the ETS, but later took up opposition against it as they objected to the speed at which it would be implemented across all sectors of the economy. Despite losing support from the National Party at the last minute, the Labour Government was able to cobble together support for climate change legislation that it was able to pass the ETS in 2008.

The social networks in focus here are advocacy coalitions which mobilized either for or against the ETS within New Zealand civil society in the lead up to the nation's Kyoto commitment period. The advocacy coalition around creating a domestic emissions trading scheme within New Zealand is characterized by a high degree of connectivity between actors within the network. Clark's Labour Government created the cabinet position of Minister of Climate Change and this actor holds a high degree of centrality within the network along with Ministry for the Environment and the Labour Party itself. While modularity is observable within the network (especially around the cluster of environmental NGOs), the degree of betweenness among all of the actors is relatively low, suggesting the network is relatively robust. Because the network is characterized by high measures of connectivity and low levels of betweenness, the centrally located Labour government actors were able to assert control within the network and direct the form carbon regulation would take. 


\subsection{Conclusion}

This chapter has argued for the utility of Social Network Analysis for the inter-disciplinary investigation of climate change as a social issue and problem. SNA can integrate the effects of ideas from the social and natural sciences and the humanities upon the fields of discourse and action around climate change. Examining the structure and flow of different kinds of social networks around climate change reveals patterns of understanding and action that shape the social response to climate change and other problems. Examining both discourse networks and advocacy coalitions, the chapter has developed an initial comparison of differences in how three societies, Japan, New Zealand, and the United States, have been framing and responding to climate change, The chapter, drawing upon early results from the project Comparing Climate Change Policy Networks (Compon), illustrates the great potential of the network approach for the inter-disciplinary study of climate change and society cross-nationally.

Open Access This chapter is distributed under the terms of the Creative Commons Attribution Noncommercial License, which permits any noncommercial use, distribution, and reproduction in any medium, provided the original author(s) and source are credited

\section{References}

Abrahamson, E., \& Rosenkopf, L. (1997). Social network effects on the extent of innovation diffusion: A computer simulation. Organization Science, 8(3), 289-309.

Baker, V. R. (2007). Flood hazard science, policy, and values: A pragmatist stance. Technology and Society, 29, 161-168. (167)

Baldassarri, D., \& Diani, M. (2007). The integrative power of civic networks. American Journal of Sociology, 113(3), 735-780.

Beck, U. (1992). Risk society. Towards a new modernity. London: Sage.

Beck, U. (2002). A life of one's own in a runaway world: Individualization, globalization and politics. In U. Beck \& E. Beck-Gernsheim (Eds.), Individualization institutionalized individualism and its social and political consequences (pp. 22-29). London: Sage.

Blau, P. M. (1977). Inequality and heterogeneity. New York: Free Press.

Bodin, Ö., \& Prell, C. (2011). Social networks and natural resource management: Uncovering the social fabric of environmental governance. Cambridge/New York: Cambridge University Press.

Bodin, Ö., Crona, B., \& Ernstson, H. (2006). Social networks in natural resource management: What is there to learn from a structural perspective? Ecology \& Society, 11(2), 395-402.

Borgatti, S. P., \& Foster, P. C. (2003). The network paradigm in organizational research: A review and typology. Journal of Management, 29(6), 991-1013.

Bott, E. (1957). Family and social network. London: Tavistock.

Boykoff, M. T., \& Boykoff, J. M. (2004). Balance as bias: Global warming and the US prestige press. Global Environmental Change, 14, 125-136.

Broadbent, J. (1998). Environmental politics in Japan: Networks of power and protest. Cambridge: Cambridge University Press.

Broadbent, J. (2001). Social capital and labor politics in Japan: Cooperation or cooptation? In J. Montgomery \& A. Inkeles (Eds.), Social capital as a policy resource in Asia and the Pacific Basin (pp. 81-95). Boston: Kluwer Academic Publishers. 
Broadbent, J. (2003). Movement in context: Thick networks and Japanese environmental protest. In M. Diani \& D. McAdam (Eds.), Social movements and networks: Relational approaches to collective action (pp. 204-229). New York: Oxford University Press.

Broadbent, J. (2005). Japan's environmental politics: Recognition and response processes (chapter 5). In H. Imura \& M. Schreurs (Eds.), Environmental management in Japan. Washington, D.C.:The World Bank and Northampton, MA: Edward Elgar.

Broadbent, J. (2008). Japan's butterfly state: Reciprocity, social capital and embedded networks in U.S. and German comparison. Unpublished.

Broadbent, J. (2010). Science and climate change policy making: A comparative network perspective. In A. Sumi, K. Fukushi, \& A. Hiramatsu (Eds.), Adaptation and mitigation strategies for climate change. Tokyo: Springer.

Broadbent, J., Yun, S-J., Ku, D., Ikeda, K., Satoh, K., Pellissery, S., Swarnakar, P., Lin, T-L., Jin, J. (2013). Asian societies and climate change: The variable diffusion of global norms. Globality Studies Journal (\#34). Retrieved from http://globality.cc.stonybrook.edu/wpcontent/uploads/2013/07/032JBroadbent.pdf

Brown, G. E., Jr. (1992). Global change and the new definition of progress. Geotimes, 18(21), 19-21.

Brown Weiss, E., \& Jacobson, H. K. (Eds.). (1998). Engaging countries: Strengthening compliance with international environmental accords. Cambridge, MA: MIT Press, 533pp.

Burridge, S., Vaughter, P., Fisher, D. R., \& Weber, J. (2013). A hot mess: Climate change issue definition (or a lack thereof) in the United States News Media. Unpublished manuscript.

Burt, R. S. (1992). Structural holes: The social structure of competition. Cambridge: Harvard University Press.

Burt, R. (2003). The social capital of structural holes. In M. F. Guillen, R. Collins, P. England, \& M. Meyer (Eds.), The new economic sociology: Developments in an emerging field (pp. 148-189). New York: Russell Sage.

Clayton, H. et al. (2006). Is a cross-party consensus on climate change possible - or desirable? (Report of the first inquiry of the All Parliamentary Climate Change Group). London: HMSO.

Coleman, J. S. (1990). Foundations of social theory. Cambridge: Belknap Press.

Collins, H., \& Evans, R. (2007). Rethinking expertise. Chicago: University of Chicago Press.

Crona, B., \& Bodin, Ö. (2006). What you know is who you know? Communication patterns among resource users as a prerequisite for comanagement. Ecology \& Society, 11(2), 290-312.

Di Gregorio, M. (2012). Networking in environmental movement organization coalitions: Interest, values or discourse? Environmental Politics, 21(1), 1-25.

Evans, P. B., Jacobson, H. K. J., \& Putnam, R. D. (1993). Double-edged diplomacy: International bargaining and domestic politics. Berkeley: University of California Press.

Folke, C., Hahn, T., Olsson, P., \& Norberg, J. (2005). Adaptive governance of social-ecological systems. Annual Review of Environment and Resources, 30, 441-473.

Frank, K. A., \& Yasumoto, J. Y. (1998). Linking action to social structure within a system: Social capital within and between subgroups 1. American Journal of Sociology, 104(3), 642-686.

Ghimire, S. K., McKey, D., \& Aumeeruddy- Thomas, Y. (2004). Heterogeneity in ethnoecological knowledge and management of medicinal plants in the Himalayas of Nepal: Implications for conservation. Ecology and Society, 9(3), 6.

Giddens, A. (2009). The politics of climate change (pp. 59-73). Cambridge: Polity Press.

Gouldson, A., Lidskog, R., \& Wester-Herber, M. (2007). The battle for hearts and minds. Evolutions in organisational approaches to environmental risk communication. Environment and Planning C, 25(1), 56-72.

Granovetter, M. (1985). Economic action and social structure: The problem of embeddedness. American Journal of Sociology, 91, 481-510.

Gustafsson, K., \& Lidskog, R. (2012). Acknowledging risk, trusting expertise, and coping with uncertainty: Citizens deliberations on spraying an insect population. Society and Natural Resources, 25, 587-601.

Hajer, M., \& Versteeg, W. (2005). Performing governance through networks. European Political Science, 4(3), 340-47. 
Hamilton, C. (2007). Scorcher: The dirty politics of climate change (p. 147). Melbourne: Black Ink Agenda.

Helm, D. (2005). Climate-change policy. New York: Oxford University Press.

Höijer, B., Lidskog, R., \& Uggla, Y. (2006). Facing dilemmas. Sense-making and decision-making in late modernity. Futures, 38, 350-366.

IPCC. (2007a). Climate Change 2007: The physical science basis: Intergovernmental Panel on Climate Change.

IPCC (Intergovernmental Panel on Climate Change). (2007b). Summary for policymakers. In: Climate Change 2007: Impacts, adaptation and vulnerability. Contribution of Working Group II to the fourth assessment report of the Intergovernmental Panel on Climate Change. Cambridge/New York: Cambridge University Press. Retrieved February 1, 2008, http://www. ipcc.ch/pdf/assessment-report/ar4/wg2/ar4-wg2-spm.pdf

Jacobson, H., \& Weiss, E. B. (1998). A framework for analysis. In E. B. Weiss \& H. Jacobson (Eds.), Engaging countries: Strengthening compliance with international environmental accords (pp. 1-18). Cambridge, MA: MIT Press.

Jaeger, C., Dürrenberger, G., Kastenholz, H., \& Truffer, B. (1993). Determinants of environmental action with regard to climate change. Climate Change, 23, 193-211.

Janicke, M. (2002). The policy System's capacity for environmental policy: The framework for comparison. In H. Weidner \& M. Janicke (Eds.), Capacity building in national environmental policy: A comparative study of 17 countries (pp. 1-18). Berlin: Springer.

Jasanoff, S. (1998). Contingent knowledge: Implications for implementation and compliance. In E. Brown Weiss \& H. K. Jacobson (Eds.), Engaging countries: Strengthening compliance with international environmental accords (p. 65). Cambridge, MA: MIT Press.

Jasanoff, S. (2005). Designs on nature. Science and democracy in Europe and the United States. Princeton: Princeton University Press.

Knoke, D., Pappi, F., Broadbent, J., \& Tsujinaka, Y. (1996). Comparing policy networks: Labor politics in the U.S., Germany and Japan. New York: Cambridge University Press.

Latour, B. (2005). Reassembling the social: An introduction to actor-network-theory. Oxford: Oxford University Press.

Laumann, E., \& Pappi, F. U. (1976). Networks of collective action: A perspective on community influence systems. New York: Academic.

Leifeld, P., \& Haunss, S. (2011). Political discourse networks and the conflict over software patents in Europe. European Journal of Political Research, 50(6).

Leifeld, P., \& Haunss, S. (2012). Political discourse networks and the conflict over software patents in Europe. European Journal of Political Research, 51, 382-409.

Lidskog, R. (2008). Scientised citizens and democratised science. Re-assessing the expert-lay divide. Journal of Risk Research, 11(1-2), 69-86.

Ministry for the Environment. (2007). New Zealand's greenhouse gas inventory 1990-2005 (The National Inventory Report and Common Reporting Format 17). Available at http://www. mfe.govt.nz/publications/climate/nir-jul07/nir-jul07.pdf

Mol, A. P. J. (2001). Globalization and environmental reform: The ecological modernization or the global economy. Cambridge, MA: MIT Press.

Mol, A., \& Sonnenfeld, D. (2000). Ecological modernization around the world: Perspectives and critical debates. London: Frank Cass.

Moyes, T. E. (2008). Greenhouse gas emissions trading in New Zealand: Trailblazing comprehensive cap and trade. Ecology Law Quarterly, 35, 911-968.

Nowotny, H., Scott, P., \& Gibbons, M. (2001). Re-thinking science. Knowledge and the public in an age of uncertainty. Cambridge: Polity Press.

Oh, H., Chung, M.-H., \& Labianca, G. (2004). Group social capital and group effectiveness: The role of informal socializing ties. Academy of Management Journal, 47(6), 860-875.

Power, M. (2007). Organized uncertainty. Designing a world of risk management. Oxford: Oxford University Press.

Prell, C. (2012). Social network analysis: History, theory and methodology. Los Angeles/London: Sage. 
Pretty, J., \& Ward, H. (2001). Social capital and the environment. World Development, 29(2), 209-227.

Reagans, R., \& McEvily, B. (2003). Network structure and knowledge transfer: The effects of cohesion and range. Administrative Science Quarterly, 48(2), 240-267.

Renn, O. (2008). Risk governance. Coping with uncertainty in a complex world. London: Earthscan.

Sabatier, P. A., \& Jenkins-Smith, H. C. (1993). Policy change and learning: An advocacy coalition approach. Boulder: Westview Press.

Schnaiberg, A., Pellow, D., \& Weinberg, A. (2003). The treadmill of production and the environmental state. In C. R. Humphrey, T. L. Lewis, \& F. H. Buttel (Eds.), Environment, energy, and society: Exemplary works (pp. 412-423). Belmont: Wadsworth Thomson Learning.

Schneider, S., Rosencranz, A., \& Niles, J. (2002). Climate change policy: A survey. Washington, DC: Island Press.

Schreurs, M. A. (2002). Environmental politics in Japan, Germany, and the United States. Cambridge/New York: Cambridge University Press.

Shearman, D., \& Wayne Smith, J. (2007). The climate change challenge and the failure of democracy (p. 133). London: Praeger.

Siegrist, M., Keller, C., \& Kiers, H. A. L. (2005). A new look at the psychometric paradigm of perception of hazards. Risk Analysis, 25(1), 211-222.

Slovic, P. (1986). Informing and educating the public about risk. Risk Analysis, 6(4), 403-415.

Speth, J., \& Haas, P. (2006). Global environmental governance. Washington, DC: Island Press.

Tompkins, E. L., \& Adger, W. N. (2004). Does adaptive management of natural resources enhance resilience to climatic change? Ecology and Society, 9(2), 10.

Tversky, A., \& Kahneman, D. (1974). Judgment under uncertainty. Heuristics and biases. Science, 185(4157), 1124-1131.

UNFCCC. (2007, November 19). Subsidiary body for implementation, compilation and synthesis of fourth national communications. Executive Summary 5, UN Doc, FCCC/SBI/2007/INF.6.

Van Dijk, E. M. (2011). Portraying real science in science communication. Science Education, 95 , $1086-1100$.

Vaughter, P. (2013). Can the Kiwi Ets Fly?: Climate Change Policy and Rhetoric within the New Zealand News Media. Unpublished manuscript.

Walls, J., Pidgeon, N., Weyman, A., \& Horlick-Jones, T. (2004). Critical trust: Understanding lay perceptions of health and safety risk regulation. Health, Risk \& Society, 6(2), 133-150.

Wasserman, S., \& Faust, K. (1997). Social network analysis: Methods and applications. New York: Cambridge University Press.

Watson, B. D. (2002). Rethinking organizational learning. Unpublished doctoral dissertation, University of Melbourne.

Weible, C. M., \& Sabatier, P. A. (2005). Comparing policy networks: Marine protected areas in California. Policy Studies Journal, 33(2), 181-202.

Weible, C. M., Sabatier, P. A., Jenkins-Smith, H. C., Nohrstedt, D., Henry, A. D., \& deLeon, P. (2011). A quarter century of the advocacy coalition framework: An introduction to the special issue. Policy Studies Journal, 39(3), 349-360.

Weidner, H., \& Janicke, M. (2002). Summary: Environmental capacity building in a converging world. In H. Weidner \& M. Janicke (Eds.), Capacity building in national environmental policy: A comparative study of 17 countries (pp. 409-443). Berlin/New York: Springer.

Weimann, G. (1982). On the importance of marginality: One more step into the two-step flow of communication. American Sociological Review, 47(6), 764-773.

Young, O. R. (2002). The institutional dimensions of environmental change: Fit, interplay, and scale. Cambridge, MA: MIT Press.

Zafonte, M., \& Sabatier, P. A. (1998). Shared beliefs and imposed interdependencies as determinants of ally networks in overlapping systems. Journal of Theoretical Politics, 10(4), 473-505. 